\title{
Extreme Weather Events Enhance DOC Consumption in a Subtropical Freshwater Ecosystem: A Multiple-Typhoon Analysis
}

\author{
Chao-Chen Lai ${ }^{1,+}$, Chia-Ying Ko ${ }^{2,3,4,+}$ (D), Eleanor Austria ${ }^{5,+}$ (D) and Fuh-Kwo Shiah $1,6,7, *$ \\ 1 Research Center for Environmental Changes, Academia Sinica, Taipei 115, Taiwan; \\ ccjosephlai@gate.sinica.edu.tw \\ 2 Institute of Fisheries Science, National Taiwan University, Taipei 10617, Taiwan; cyko235@ntu.edu.tw \\ 3 Department of Life Science, National Taiwan University, Taipei 10617, Taiwan \\ 4 Department of Biochemical Science and Technology, National Taiwan University, Taipei 10617, Taiwan \\ 5 Biology Department, Adamson University, Ermita, Manila 1000, Philippines; \\ eleanor.austria@adamson.edu.ph \\ 6 Institute of Oceanography, National Taiwan University, Taipei 10617, Taiwan \\ 7 Institute of Marine Environment and Ecology, National Taiwan Ocean University, Keelung 202, Taiwan \\ * Correspondence: fkshiah@rcec.sinica.edu.tw \\ + Co-first author.
}

check for

updates

Citation: Lai, C.-C.; Ko, C.-Y.; Austria, E.; Shiah, F.-K. Extreme Weather Events Enhance DOC Consumption in a Subtropical Freshwater Ecosystem: A Multiple-Typhoon Analysis. Microorganisms 2021, 9, 1199. https://doi.org/10.3390/ microorganisms 9061199

Academic Editor: Veljo Kisand

Received: 27 April 2021

Accepted: 27 May 2021

Published: 1 June 2021

Publisher's Note: MDPI stays neutral with regard to jurisdictional claims in published maps and institutional affiliations.

Copyright: (c) 2021 by the authors. Licensee MDPI, Basel, Switzerland. This article is an open access article distributed under the terms and conditions of the Creative Commons Attribution (CC BY) license (https:/ / creativecommons.org/licenses/by/ $4.0 /)$.

\begin{abstract}
Empirical evidence suggests that the frequency/intensity of extreme weather events might increase in a warming climate. It remains unclear how these events quantitatively impact dissolved organic carbon (DOC), a pool approximately equal to $\mathrm{CO}_{2}$ in the atmosphere. This study conducted a weekly-to-biweekly sampling in a deep subtropical reservoir in the typhoonprevailing season (June to September) from 2004 to 2009, at which 33 typhoons with distinctive precipitation $\left(<1 \sim 362 \mathrm{~mm} \mathrm{~d}^{-1}\right)$ had passed the study site. Our analyses indicated that the phosphate (i.e., DIP; $<10 \sim 181 \mathrm{nMP}$ ) varied positively with the intensity of the accumulated rainfall 2-weeks prior; bacteria growth rate $\left(0.05 \sim 3.68 \mathrm{~d}^{-1}\right)$ behaved as a positive function of DIP, and DOC concentrations (54 119 $\mu \mathrm{MC}$ ) changed negatively with bacterial production (1.2 26.1 $\left.\mathrm{mgC} \mathrm{m}^{-3} \mathrm{~d}^{-1}\right)$. These implied that the elevated DIP-loading in the hyperpycnal flow induced by typhoons could fuel bacteria growth and cause a significant decline of DOC concentrations. As the typhoon's intensity increases, many mineral-limited lentic freshwater ecosystems might become more like a $\mathrm{CO}_{2}$ source injecting more $\mathrm{CO}_{2}$ back to the atmosphere, creating a positive feedback loop that might generate severer extreme weather events.
\end{abstract}

Keywords: climatic changes; typhoons; bacteria; microbial ecology; organic carbon cycling; reservoir

\section{Introduction}

The increased appearance of extreme weather events—-such as heavy precipitation [1,2] and strong typhoons [3-5] - has been suggested to be related to increasing atmospheric $\mathrm{CO}_{2}$ and are believed to become unpredictable but prospectively with severe impacts on Earth in a warming climate [6]. In aquatic systems, these extreme weather events impose physical [7,8], biological [9], and chemical [10-13] changes that can result in climate feedbacks leading to either intensification or weakening of the magnitude of global climate change $[14,15]$. Notes that extreme weather events may act in a reverse way rendering years without typhoons and/or with extreme low rainfalls as well.

The aquatic systems' role in climate feedbacks is a consequence of the large number of organic compounds that are stored within the systems. These organics come from biogenic (or food-web) processes involving autotrophic and heterotrophic organisms or from allochthonous sources such as those carried by terrestrial run-off. Organic carbon can be roughly categorized into particulate (POC) and dissolved (DOC) phases, more than 
$90 \%$ of which are in the form of the latter [16,17]. DOC has an inventory equal to that of atmospheric $\mathrm{CO}_{2},(\sim 600$ Giga Tons $\mathrm{C})[18,19]$, therefore, when mobilized and released into the atmosphere, this large DOC reservoir could have the potential to influence climate and its change eventually.

Heterotrophic bacteria (i.e., bacteria) are the major organism responsible for the mobilization of organics particularly DOC in the aquatic systems. DOC was previously thought to be refractory to all forms of degradation and while it is known that DOC can be degraded by photochemical reactions which alter it into a labile form [20], bacterial processing remains the more significant pathway in DOC conversion [21]. Bacteria process this otherwise recalcitrant organic compound and make it available to higher consumers through the microbial loop [22,23] and concomitantly respire it to inorganic compounds, contributing $\mathrm{CO}_{2}$ back to aquatic systems. It is known that $10-90 \%$ of $\mathrm{CO}_{2}$ in the aquatic systems is produced via the heterotrophic metabolism of organic compounds [24]. Consequently, bacterial metabolism and DOC dynamics are interchangeably linked.

Environmental factors such as temperature and substrate supply [25] control the activities of bacteria. Recently, increasing interest in the influence of the extreme weather disturbances on bacterial metabolism has been arising [26,27]. As many freshwater ecosystems are primarily phosphate-limited and might be also co-limited by other chemicals like nitrogen and carbon [28], episodic supplies of these limiting nutrients-e.g., via storm's runoff [29-31] —increased the heterotrophic metabolism of organic compounds with both short-term or long-term effects [10,32-34]. The qualitative link among typhoons, limiting nutrients, and DOC dynamics (e.g., depletion and/or accumulation) in the study site [9] revealed that the phosphate pulses induced by typhoons could enhance the consumption of DOC.

To date, many studies have addressed the DOC variation in aquatic systems $[6,35,36]$. There are field observations addressing the impacts of the strong weather events such as typhoons on DOC dynamics $[8,33,37,38]$. However, related study using the data with multiple typhoon cases has been rare. The (sub) tropical ecosystems are ideal areas to observe the effects of extreme weather events on aquatic system behavior because these areas are characterized by frequent appearances of typhoons and monsoons. In this study, we used a six-year high-frequency data set to demonstrate quantitatively that the intensity of typhoon rainfall determined the supply rate of limiting nutrients that would further affect the bacterial activity and DOC consumption/accumulation rate. With an assumption that the intensity of strong and/or extreme weather events might increase with global warming, this study then proposed a positive feedback loop among typhoon rainfall intensity, and system biogenic $\mathrm{CO}_{2}$ emission rate and atmospheric $\mathrm{CO}_{2}$ concentrations, which might give rise to worse extreme weather in the future.

\section{Materials and Methods}

\subsection{Study Area}

This study was conducted in the Fei-Tsui Reservoir (FTR), a subtropical freshwater ecosystem locating in northern Taiwan $\left(121^{\circ} 34^{\prime}\right.$ E, $24^{\circ} 54^{\prime} \mathrm{N}$; Figure 1$)$. The watershed area is carved by several tributaries that drain water into the basin (area: $10.24 \mathrm{~km}^{2}$ ) and into the dam site (maximum reservoir water volume of $\sim 3.3 \times 10^{8} \mathrm{~m}^{3}$ ) where bottom depth varies from 80 to $110 \mathrm{~m}$ deep depending on the season. During the wet season (June to September), precipitation brought by afternoon thundershowers (30 40\%) and typhoons $(60 \sim 70 \%)$ are the major sources of inflow into the reservoir. Precipitation and typhoon records were taken from the Central Weather Bureau (www.cwb.gov.tw, accessed on 27 April 2021) and Taipei FTR Administration Bureau (www.feitsui.gov.tw, accessed on 27 April 2021). 


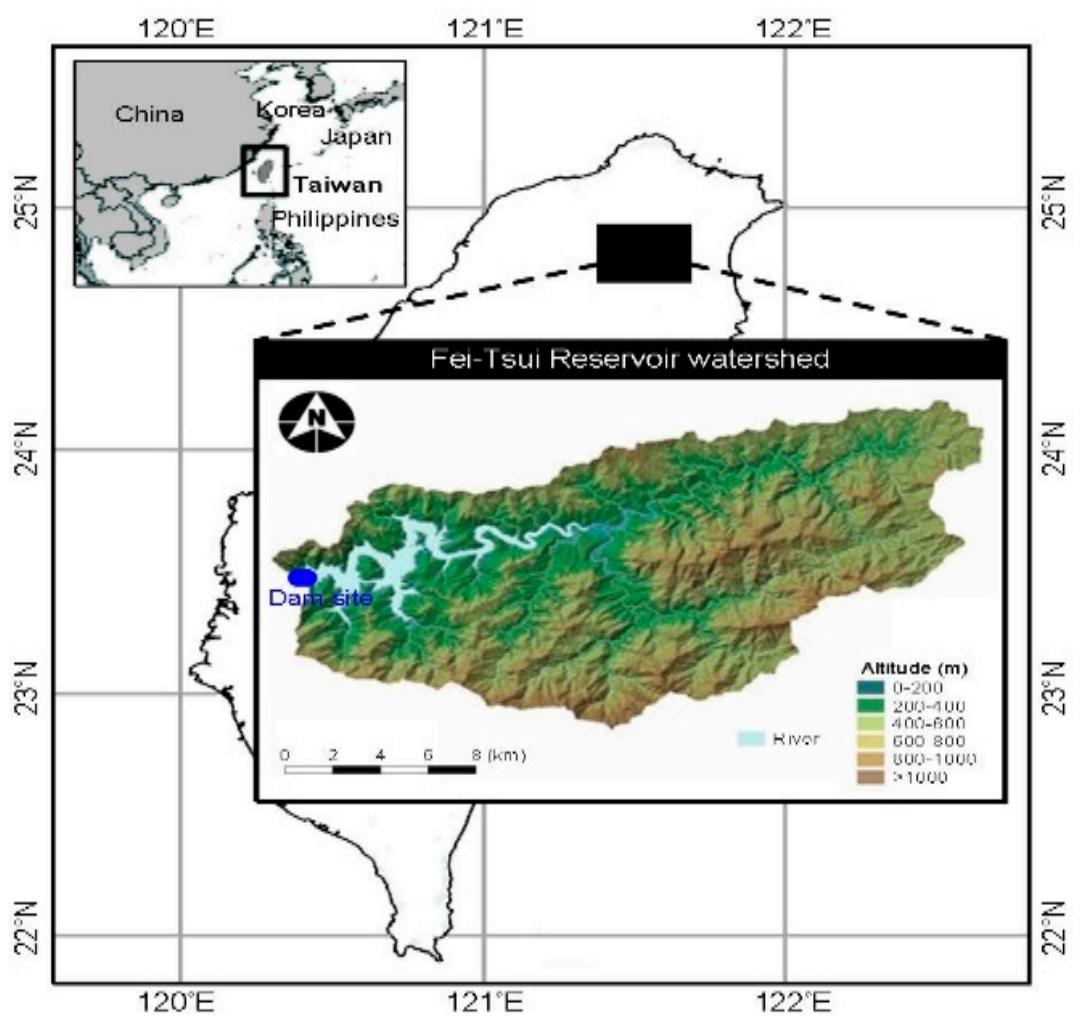

Figure 1. Location of Fei-Tsui Reservoir watershed in Taiwan showed the dam site and altitudinal distribution. The map is displayed by a WGS84 spatial reference system.

Several characteristics of FTR make it an ideal study area to investigate the influence of strong weather events (i.e., typhoon intensity) in the aquatic systems. The area is semienclosed and well protected from human activities, providing conditions for ecological studies with the least possible complicating factors. It is frequently traversed by Pacific typhoons and Asian southwest monsoon from summer to early autumn bringing variable amounts of precipitation. During a strong typhoon period, there are more typhoons with higher precipitations resulting in higher total precipitation $\left(>200 \mathrm{~mm} \mathrm{day}^{-1}\right)$. It should be noted that a previous study on the influence of typhoons on the settling flux of particles reported no difference in the particle fluxes when precipitation is $<150 \mathrm{~mm}$ for each weather event, even when the wind is strong [7]. The variability in precipitation amount allowed comparisons between strong and weak typhoon periods [9].

\subsection{Filed Sampling and Measurements}

Sampling was conducted in the dam site weekly to biweekly in the wet season (JuneSeptember) from 2004 to 2009 . Water samples were taken from 10 specified depths (surface, $2,5,10,15,20,30,50,70,90 \mathrm{~m}$ ) using 5L Go-Flo bottles and were placed in a 20L opaque carboy. In the laboratory, 300 500 mL of water samples were first filtered through a GF/F filter (pore size of $0.7 \mu \mathrm{m}$ ) for DOC measurement. The filtrates were then acidified with $80 \%$ $\mathrm{H}_{3} \mathrm{PO}_{4}$ and sprayed with $\mathrm{CO}_{2}$-free $\mathrm{O}_{2}$ at a flow rate of $350 \mathrm{~mL} \mathrm{~min}{ }^{-1}$ for at least $10 \mathrm{~min}$. The DOC was measured on a Shimadzu TOC-5000 high-temperature catalytic oxidation analyzer. The phosphate samples were also first filtered (GF/F filter, pore size of 0.4 to $0.6 \mu \mathrm{m}$ ) and measured via a custom-made flow injection analyzer using a $10 \mathrm{~cm}$ detection cell [9].

The flow cytometry procedures $[39,40]$ were followed for heterotrophic bacteria counts. $100 \mathrm{~mL}$ of water samples were fixed with final concentrations of $0.1 \%$ glutaraldehyde, then frozen with liquid nitrogen and stored at $-80^{\circ} \mathrm{C}$. Samples were stained with SYBR-GREEN I and then incubated for $15 \mathrm{~min}$ at room temperature in the dark. The samples were run in a flow cytometer of CyFlow ${ }^{\circledR}$ Space (PARTEC) at a rate allowing $<1000$ events sec $^{-1}$ 
to avoid particle coincidence. Bacteria production was determined by the ${ }^{3} \mathrm{H}$-thymidine incorporation method [41]. Each depth of bacterial production samples was analyzed in triplicate, $20 \mu \mathrm{L}^{3} \mathrm{H}$-thymidine was added to the water samples and incubated at in situ temperature on board for two hours. Formaldehyde was then added to stop the incubation. The fixed samples were centrifuged, aspirated, and rinsed using ice-cold $5 \%$ tricarboxylic acid and ice-cold $80 \%$ ethanol. A scintillation cocktail (Ultima Gold, Packard) was added to the samples before placing them on the beta counter (Packard 2200) for the detection of radioactivity. A thymidine conversion factor of $2.81 \times 10^{18}$ cell per mole [9] and a carbon conversion factor of $20 \mathrm{fgC}$ per cell [42] were used to derive bacterial abundance and production in the carbon unit. Bacterial (per cell) growth rate was calculated by diving production with biomass. Bacterial carbon demand was calculated by dividing production with a growth efficiency of $20 \%$ [42].

\subsection{Data Analysis}

Integrated values of the measurements taken from the 10 depths were computed using the trapezoidal method. The values were then divided by the deepest sampling depth as the depth-averaged values. Linear regression (model II) was used to estimate relationships among physical (typhoon-induced precipitation), chemical (phosphate and DOC), and biological (bacteria production and growth rate) variables. The DOC inventory depletion/increase rate was calculated based on differences between the measurements recorded on consecutive sampling dates. The total precipitation that had been accumulated during the 14 days before the sampling date was defined as the prior accumulated precipitation.

\section{Results}

\subsection{Precipitation Pattern and Typhoon Distribution}

A total of 33 typhoons with various precipitation intensities (Figure 2; 0 361 $\mathrm{mm} \mathrm{d}^{-1}$ ) swept through the study site from 2004 to 2009 (Table S1). The grand averaged typhoon precipitation varied $>2$-fold inter-annually with the highest $\left(287 \mathrm{~mm} \mathrm{~d}^{-1}\right)$ and lowest $\left(112 \mathrm{~mm} \mathrm{~d}^{-1}\right)$ values recorded in 2005 and 2006, respectively. Higher grand annual rainfalls $\left(>250 \mathrm{~mm} \mathrm{day}^{-1}\right.$ ) was recorded in 2004, 2005, and 2007, which were designated as the strong typhoon years, while the rest years were assigned as the weak typhoon year. Noted that the four maximal typhoon daily precipitations in $2007\left(60 \sim 195 \mathrm{~mm} \mathrm{~d}^{-1}\right)$ were in an intermediate level; however, their accumulated (and the grand average) precipitations ranked the highest. Similarly, a typhoon (i.e., Sinlaku) with very high precipitation $\left(>300 \mathrm{~mm} \mathrm{~d}^{-1}\right)$ occurred in 2008, but the grand averaged precipitation over the summer season of that year was low with a value of $190 \pm 306 \mathrm{~mm} \mathrm{~d}^{-1}$.

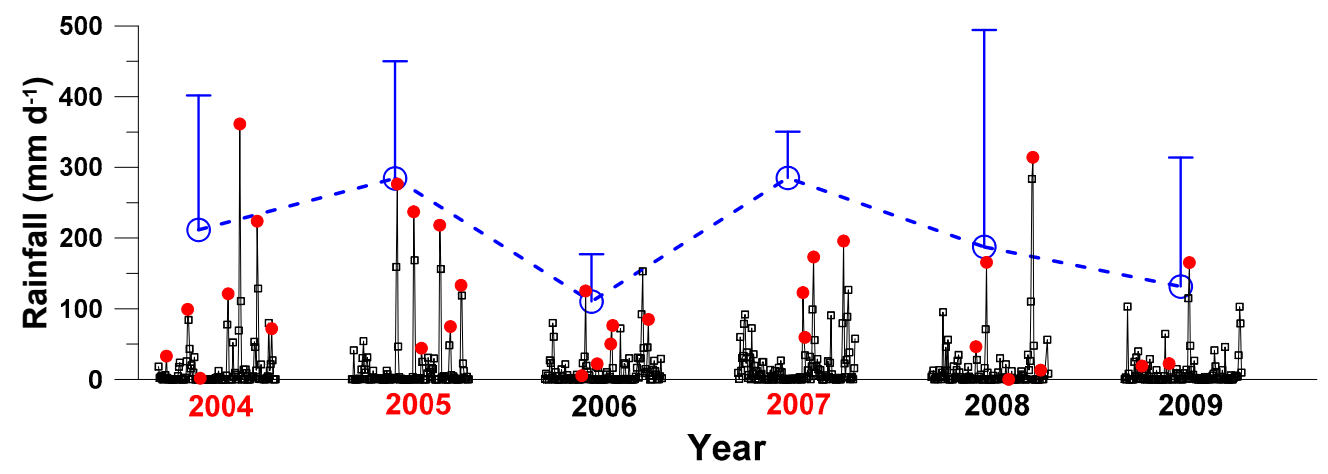

Figure 2. Wet season (June to September) daily precipitation (black open squares), the highest typhoon daily precipitation during its visiting period (red solid dots), and the grand averages of total typhoon precipitation in summer season (blue open circles) recorded from 2004 to 2009. Vertical bars denoted standard deviation. Years in red color denoted strong-typhoon years. 


\subsection{Depth Contours and Depth-Averages of Measurements}

DOC concentrations (Figure 3a) varied from 40 to $149 \mu \mathrm{MC}$ and were usually higher on the surface, and then decreased with depth. The $80 \mu \mathrm{MC}$ isovalue lines in 2004 and 2005 fluctuated over the upper $10 \mathrm{~m}$. In 2006, when typhoon impact was the weakest, very high DOC with concentrations $>160 \mu \mathrm{MC}$ were recorded from mid-July to the end of September; the $80 \mu \mathrm{MC}$ isovalue lines penetrated down to $60 \mathrm{~m}$ depth in mid-July, and then to $90 \mathrm{~m}$ depth in late August. For the following three years, though less significant than that of 2006, the $80 \mu \mathrm{MC}$ isovalue lines could still be observed frequently in mid- to deep-water areas.

Vertical profiles of phosphate concentrations (Figure 3b) in 2004, 2005, and 2007 revealed significant subsurface plumes (>100 nMP) occurring at depths of $30 \sim 80 \mathrm{~m}$, reflecting the footprint of hyperpycnal flow induced by typhoons. In comparison, the subsurface phosphate plumes in weak typhoon years were less significant than those of strong typhoon years. Note that subsurface phosphate plume could exist at mid-water depth for weeks or even covered the whole summer as occurred in strong typhoon years. Profiles of bacterial production (Figure 3c) denoted higher bacterial activity in the surface, decreasing with depth but occasionally elevated near the bottom. Several cases, especially in 2004 and 2005, showed high bacterial production $\left(>10 \mathrm{mgC} \mathrm{m}^{-3} \mathrm{~d}^{-1}\right)$ throughout the water column.
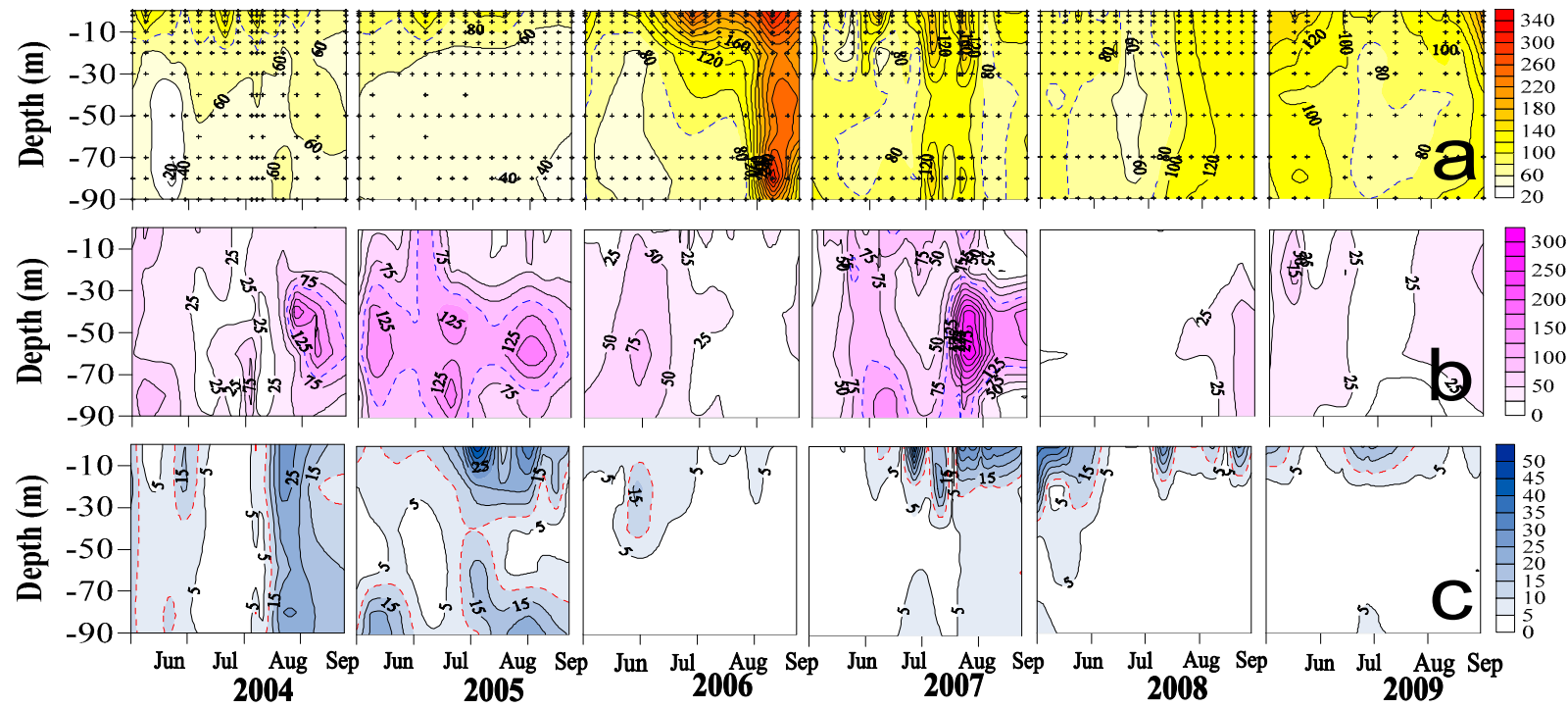

Figure 3. Depth contours of (a) DOC concentrations ( $\mu \mathrm{MC})$, (b) phosphate concentrations (nMP) and (c) bacterial production $\left(\mathrm{mgC} \mathrm{m}^{-3} \mathrm{~d}^{-1}\right)$ recorded in the warm season (June to September) from 2004 to 2009. Dash lines in panels (a-c) represented the $80 \mu \mathrm{MC}, 100 \mathrm{nMP}$, and $10 \mathrm{mgC} \mathrm{m}^{-3} \mathrm{~d}^{-1}$ isovalue lines, respectively.

The depth-averaged DOC concentrations varied $\sim 8$-folds inter-annually with values ranged 33 262 $\mu \mathrm{MC}$ (Figure 4a). The highest DOC grand average and variation (i.e., standard deviation) were found in 2006. The averaged phosphate concentrations ranged from $<1$ to $181 \mathrm{nMP}$ (Figure 4b). The highest grand averages were recorded in 2005 and 2007 while the lowest value was seen in 2008 . The depth-averaged bacterial production (Figure $4 \mathrm{c}$ ) ranged from $<1$ to $25 \mathrm{mgC} \mathrm{m} \mathrm{m}^{-3} \mathrm{~d}^{-1}$ with the highest depth-averaged values seen in 2004 and 2005, and the lowest annual means appeared in 2009. 


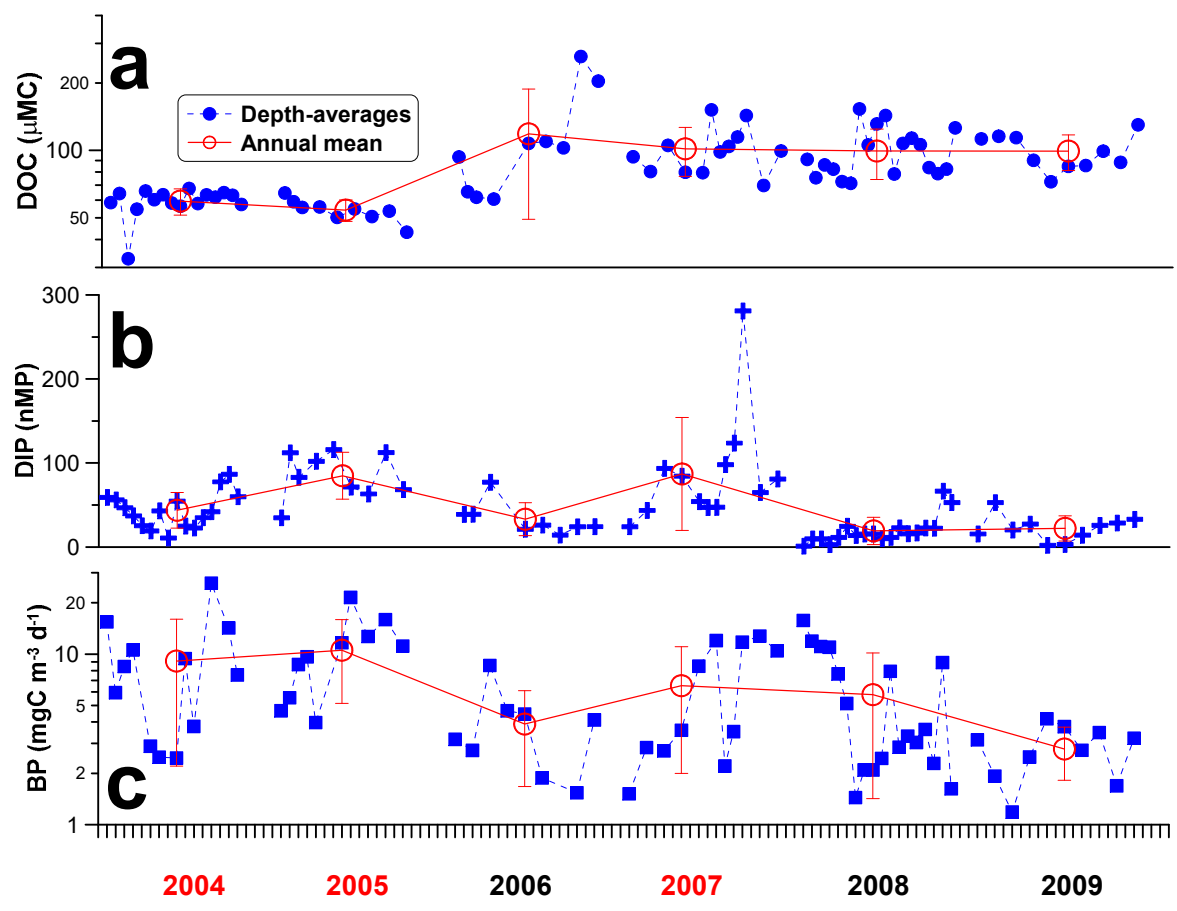

Figure 4. Inter-annual variation of the depth-averages of (a) dissolved organic carbon concentrations (DOC), (b) phosphate concentrations (DIP), and (c) bacterial production (BP). Red open circles indicated the grant averages of the measurements of each season. Vertical bars denoted standard deviation. Years in red color denoted strong-typhoon years.

The DOC accumulation and depletion rates (Figure 5) varied nearly almost 100-folds ranging from 0.13 to $23.8 \mu \mathrm{MC} \mathrm{d}^{-1}$ and 0.14 to $12.2 \mu \mathrm{MC} \mathrm{d}^{-1}$, respectively. The largest variation in both rates occurred in year 2007, and those of year 2008 ranked the second.

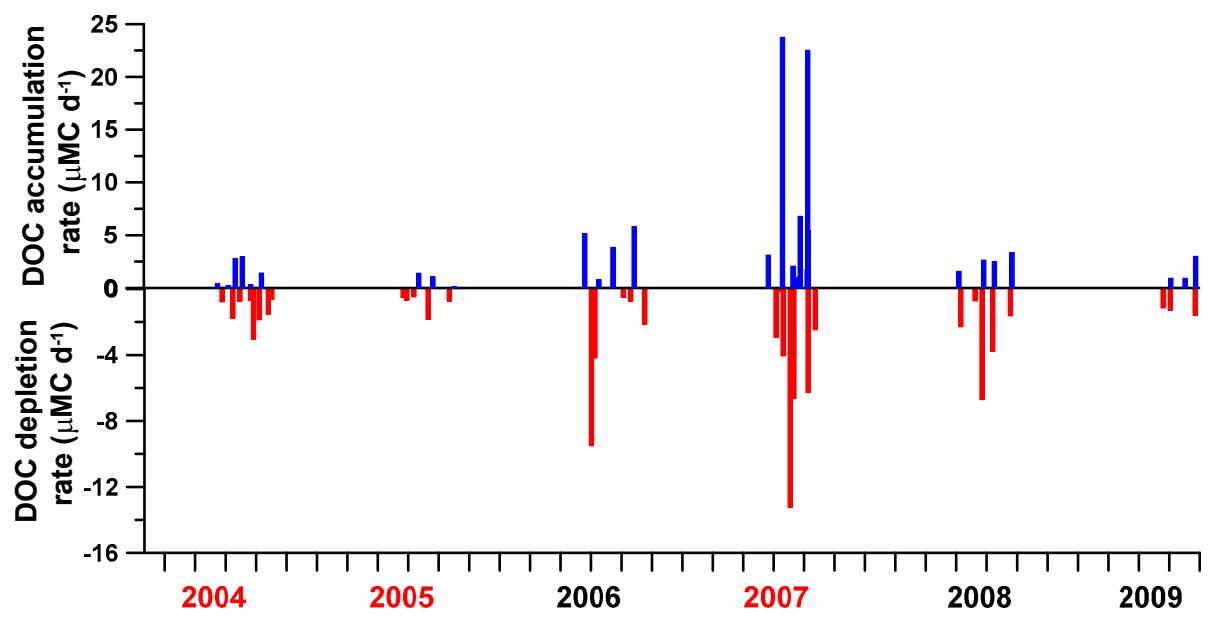

Figure 5. DOC accumulation (blue bars) and depletion (red bars) rates calculated from the difference of the depth-averaged DOC shown in Figure $4 \mathrm{a}$. The changing rates $< \pm 0.1 \mu \mathrm{MC} \mathrm{d}^{-1}$ were not included. Years in red color denoted strong-typhoon years.

\subsection{Statistical Relationships among Measurements}

The inter-annual variations in the depth-averaged phosphate concentrations behaved as a positive function of the prior accumulated precipitation (Figure 6a). Bacteria (per cell) growth rate varied positively with the depth-averaged phosphate concentrations (Figure $6 \mathrm{~b}$ ). The depth-averaged bacterial production was negatively correlated with the depth-averaged DOC concentrations (Figure 6c). Interestingly but not surprisingly, DOC inventory depletion rates (Figure 5; range $0.14 \sim 12.2 \mu \mathrm{MC} \mathrm{d}^{-1}$ ) were very close to those of 
bacterial carbon demand (range $<1 \sim 10.3 \mu \mathrm{MC} \mathrm{d}^{-1}$ ) derived from our bacterial production. Our further analysis indicated that the DOC changing (e.g., accumulation and depletion) rates varied negatively with bacterial production (Figure $6 \mathrm{~d}$ ).
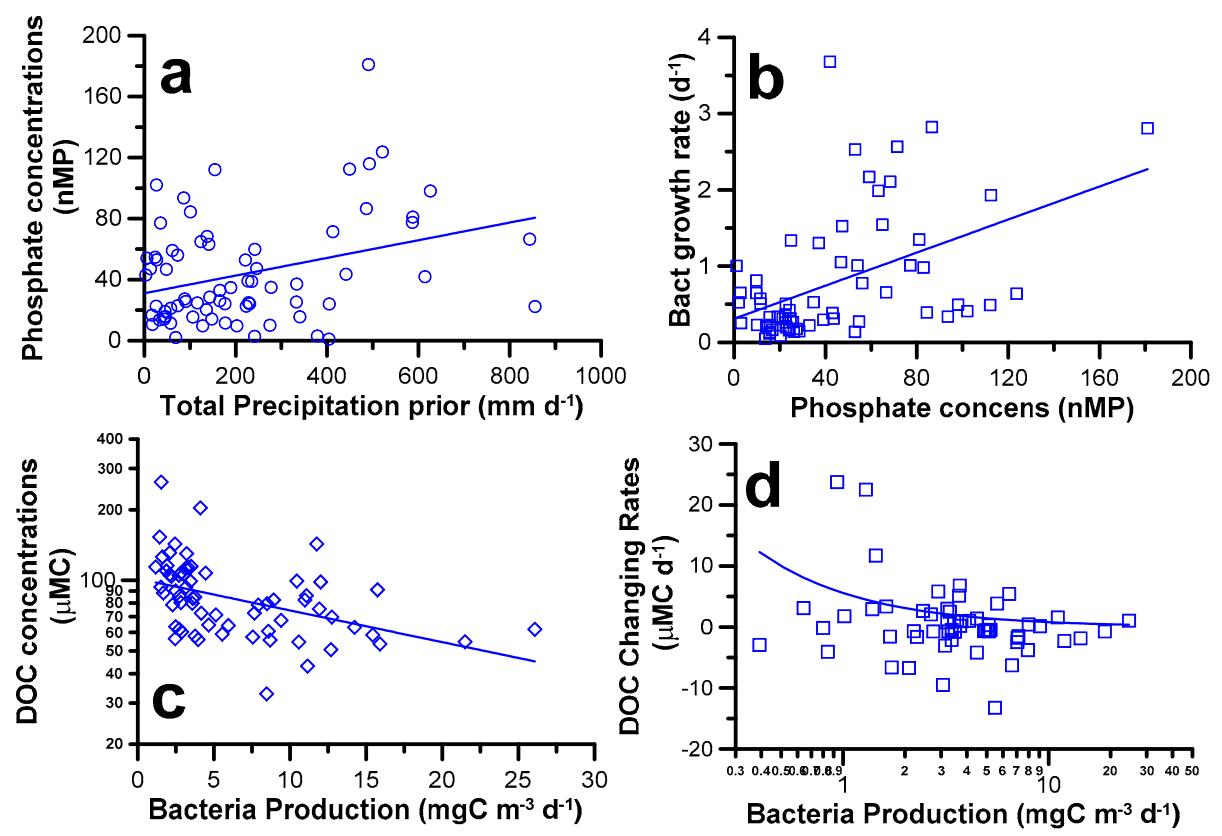

Figure 6. The best fit equations for the regression of the depth-averaged (a) phosphate concentrations vs. the prior accumulated precipitation (linear fit, $n=66, \mathrm{r}^{2}=0.11$ ), (b) bacteria growth rate vs. phosphate concentrations (linear fit, $n=64, \mathrm{r}^{2}=0.23$ ), and (c) dissolved organic carbon (DOC) concentrations vs. bacteria production (exponential fit, $n=66, \mathrm{r}^{2}=0.23$ ), and (d) dissolved organic carbon accumulation/depletion rates vs. bacterial production (power fit, $n=27, \mathrm{r}^{2}=0.28$ ). All regression lines were significant at $p=0.01$ level. Additional characters, $n$ and $\mathrm{r}^{2}$ indicated sampling size and coefficients of determination respectively.

\section{Discussion}

\subsection{Ecosystem Subjected to Multiple-Typhoon Impacts}

The extreme weather events have been suggested to be the main factor influencing heterotrophic bacterial activity resulting in an increase of organic compounds' mineralization and a net heterotrophy in the aquatic systems $[10,27]$. As the amount of $\mathrm{CO}_{2}$ produced in the aquatic systems determines the efflux of $\mathrm{CO}_{2}$ to the atmosphere, typhoons and heavy precipitation that stimulate heterotrophic metabolism can result in increased $\mathrm{CO}_{2}$ evasion from water bodies contributing further to the increasing concentrations of atmospheric $\mathrm{CO}_{2}$. However, as intuitive as it seems, quantitative studies on the link between extreme weather events, limiting nutrients, bacterial activity, and DOC consumption has been lacking. That is, multiple-typhoon analysis using long-term data sets has been limited until recently.

Additionally, it is aware that most of the long-term studies were conducted in the northern zones of the northern hemisphere [43] where there are no periodic/frequent disturbances by typhoons and other types of strong weather events. Based on our results, the appearance of multiple typhoons did significantly influence the DOC dynamics in the aquatic systems. Our study is the first to demonstrate positive relationships between multiple summer typhoons, phosphate concentrations, and bacterial production, and deduced how this led to a negative DOC vs. bacteria C-consumption correlation. 


\subsection{DOC Long-Term Trend and Dynamics}

Several long-term studies have reported a trend of increasing DOC concentrations in the aquatic systems [44], implicating the increasing atmospheric $\mathrm{CO}_{2}$ and land use changes due to anthropogenic activities [45]. We did not observe a long-term increase in DOC concentrations in this study. Instead, our data showed huge intra- and inter-annual variations in terms of DOC concentrations (Figures 3a and 4a) and its changing (accumulation/depletion) rates (Figure 5). We reasoned that this might due to frequent typhoon impacts (Figure 2) on limiting-nutrient loading (Figure 3a) and thus rapid consumption of DOC (Figure 3b) as a result of elevated bacteria activity (Figure 3c). This is one of the findings that makes our study unique.

Considerable local runoff caused by typhoons and heavy precipitation adds to carry terrestrially-derived organic material into the system inducing organic enrichment [43,46-48]. However, the high DOC concentrations observed in the water column when typhoons approached were not due to contributions from the runoff during the previous basinwide investigation of the study area [9], which had demonstrated that tributary inflows during the typhoon period had no direct enrichment effect on the DOC at the dam site. Instead, the observed negative relationship between DOC concentrations and bacteria production (Figure 6d) and thus their DOC consumption capacity could be linked to the availability of limiting nutrients, specifically phosphate. This was also supported by bioassay results from this site [9] which indicated that DOC bio-degradation rates derived from the bioassay experiments using the FTR water samples changed positively with in situ phosphate concentrations.

Furthermore, there is evidence supporting the view that bacteria production and thus their carbon consumption capacity played a crucial role in determining the variation of DOC inventory in this ecosystem. Note that the DOC inventory depletion rates $\left(<1 \sim 12.2 \mu \mathrm{MC} \mathrm{d}^{-1}\right)$ and bacterial carbon demand (range $\left.<1 \sim 10.3 \mu \mathrm{MC} \mathrm{d}^{-1}\right)$ of our study were in range with the bio-degradation rates $\left(2.3 \sim 18.3 \mu \mathrm{MC} \mathrm{d}^{-1}\right)$ [9] derived from the same experiment site. Secondly, the negative function of DOC changing rates vs. bacteria production (Figure 6d) highlighted a possible scenario that DOC inventory accumulation rate tended to be high when bacteria activity was low. The accumulation rate was diminishing and then switched to a state of increasing depletion rate accompanied by a decreasing bacteria activity. All these suggesting that elevated DOC in this ecosystem, typically resistant to rapid microbial re-mineralization, could be made bio-available to bacterial consumption.

\subsection{Transportation of Limiting Mineral by Typhoon Rainfall}

Aside from the nutrient enrichment, the runoff export of dissolved and particulate materials as well as physical disturbances such as mixing both associated with typhoons and heavy precipitation $[48,49]$ subsequently forming a so-called hyperpycnal flow, which was first reported by [50] in Lake Leman and has been frequently observed in many lake systems [51,52]. When the typhoon-induced runoff entrains high concentrations of suspended materials, the hyperpycnal flow is produced when the density of river water entering the basin (or the dam site in this study) is greater than the density of the surrounding water. This is fairly common in Taiwan due to frequent earthquakes and periodic typhoons with heavy precipitation [9,53]. In the FTR watershed, when supplied through a deep (60 80 m below surface) transport below the euphotic zone. The elevated phosphate downstream loading (see also next paragraph) induced by the aforementioned events was the major driving force in relieving bacteria from limitation, resulting in increased bacterial consumption of DOC and increased oxidation to $\mathrm{CO}_{2}$.

A great part of the phosphate in soil/sediments is adsorbed onto the surface of the fine particles or incorporated into soil/sediments' organic matter. The export of sediment particles from the tributaries to the dam site could be affected by the hydrological condition (e.g., typhoon precipitation's intensity), the geology, and the soil composition. The release of phosphate from these particles at the dam site could be influenced by temperature 
and the Redox ( $\mathrm{pH} /$ anoxia) etc. Phosphate's solubility is controlled by either sorptiondesorption or coagulation-dissolution reactions depending on the environment $[54,55]$. Moreover, there was a time lag between the occurrence of typhoon-induced sediment flush at the tributaries and the corresponding high phosphate concentrations at the dam site. For example, in 2004, the highest typhoon precipitation occurred on 24 August (Figure 2), while higher depth-averaged phosphate concentrations were recorded on 14 September (Figure $4 \mathrm{~b}$ ). Similarly, we observed very high (124 281 nMP) depth-averaged phosphate concentrations on 22 and 23 August 2007 which were believed to be affected collectively by the two consecutive intermediate typhoons that had occurred previously on 6 and 18 August.

All these addressed that the linkage among the upstream tributaries flushing of sediment-adsorbed phosphate to the dissolved inorganic phosphate concentrations recorded at the dam site had been completed by the time lag and a series of complex physical and chemical processes. This could be the main reason for the low $\mathrm{r}^{2}$ value for the regression (significant though) of the prior accumulated precipitation vs. phosphate concentrations as shown in Figure 6a. Note that the long-lasting subsurface phosphate plumes recorded in strong typhoon years (2005 and 2007; Figure $3 b$ ) could serve as a long-term mineral source fueling high bacterial growth (Figures $3 \mathrm{c}$ and $6 \mathrm{~b}$ ) and their carbon consumption (Figure $6 \mathrm{c}$ ) in the dam site.

\subsection{Potential Impacts and Feedback on C-Cycling}

Heterotrophic bacteria are mainly responsible for the consumption of DOC, the fate of which varies according to the source or quality of the organic compound. Several studies indicate that the source of DOC determines whether it is readily incorporated as biomass. As the watershed in the study area is well protected, the DOC mostly comes from phytoplankton production giving it a labile to semi-labile characteristic [9]. Bacteria can consume this DOC and respire it. Allochthonous DOC was previously thought to be recalcitrant to bacterial degradation but increasing evidence now exists that bacteria can process this recalcitrant DOC and respire a large amount of it in the receiving body of water resulting in net heterotrophy of the system [56]. Although bacterial consumption of allochthonous DOC was not significant in this study, the implications of our findings to climate feedbacks can be significant in the ecosystems that are subjected to irregular disturbance from extreme weather events. In these areas, enhanced terrestrial-originated mineral loadings can support the increasing bacterial activity, and eventually giving rise to elevated $\mathrm{CO}_{2}$ production and evasion from the water body. It is evidenced by several studies showing inland waters to be supersaturated with $\mathrm{CO}_{2}$ and known as hotspots of $\mathrm{CO}_{2}$ with a global evasion rate of $2.1 \mathrm{PgC}^{-1}[57,58]$.

Recent studies have predicted that global warming might amplify intensities of typhoons [5] and extreme precipitation [1,2] in the future. Accordingly, it is highly likely that in a warming climate, freshwater ecosystems subjected to strong extreme weather events might become more of a $\mathrm{CO}_{2}$ source rendering higher $\mathrm{CO}_{2}$ concentrations in the atmosphere, warmer temperature, and more severe extreme weather events. We reason that as the intensities of extreme precipitation and/or typhoons increase due to warming, the loading of limiting nutrients might be enhanced through the hyperpycnal flow mechanism. This so-called 'new nutrient' eventually fuels higher bacterial growth and their DOC consumption rate, making the aquatic system a stronger $\mathrm{CO}_{2}$ source and make the atmospheric system with higher $\mathrm{CO}_{2}$ concentrations (Figure 7). Conversely, if typhoon number and/or intensity diminish under a warming climate, then it is expected to see this watershed becomes a system with escalating DOC inventory. 


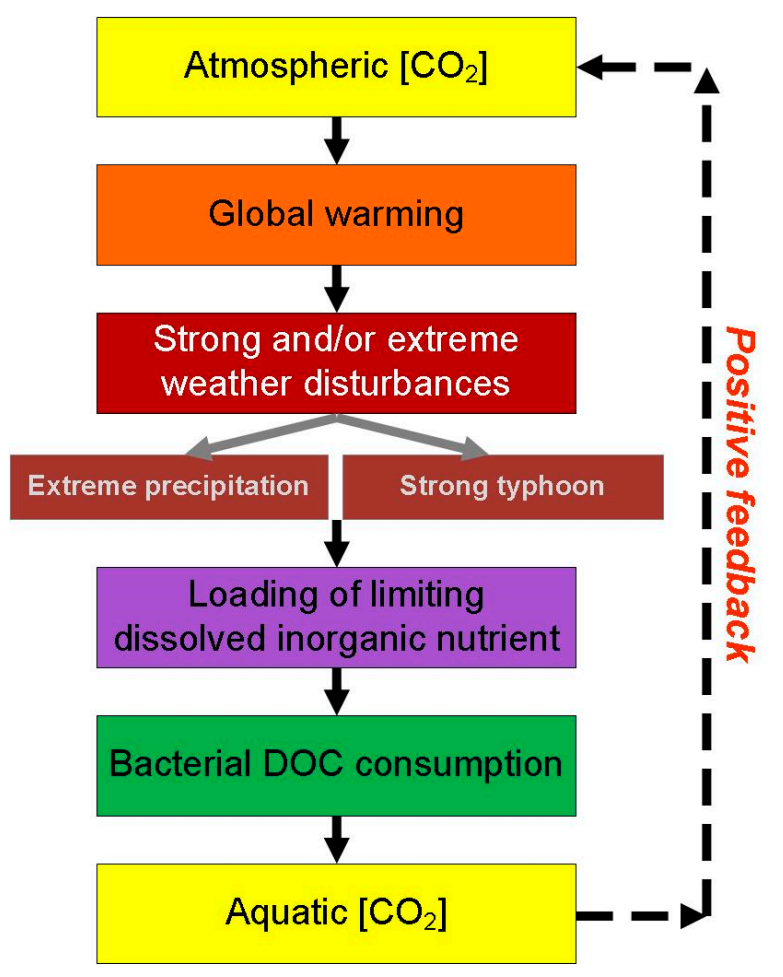

Figure 7. A hypothetic model showed the feedback loop of extreme weather events on the supply rates of limiting nutrient, bacterial activity, dissolved organic carbon inventory, and thus $\mathrm{CO}_{2}$ concentrations in both aquatic and atmospheric systems.

\section{Conclusions}

Under phosphate-limited conditions, in situ DOC inventory tends to accumulate due to low bacterial activity. The new phosphate induced by the strong weather events (e.g., typhoons) via hyperpycnal flow substantially stimulates bacterial carbon consumption capacity and weakens the system's capacity in storing autochthonous DOC. Overall, it is hypothesized that in the perspective of aquatic biogeochemistry, extreme weather events might make the future warming climate worse. The findings and deduction of this study may expand our current perception of the cycling and export of biogenic DOC in lentic ecosystems in a warming world.

Supplementary Materials: The following is available online at https:/ / www.mdpi.com/article/10 $.3390 /$ microorganisms9061199/s1. Table S1: Recorded typhoons that had visited Taiwan during the period of 2004-2009.

Author Contributions: C.-C.L. and E.A. performed chemical and bacteria measurements. C.-Y.K. analyzed the data. F.-K.S. designed the study and wrote the manuscript with C.-Y.K. All authors have read and agreed to the published version of the manuscript.

Funding: This work was financially supported by RCEC of Academia Sinica and the Ministry of Sciences and Technology (MOST) of Taiwan. CYK thanks funding support by MOST Young Scholar Fellowship Columbus Program, under grants: 107-2611-M-002-005-, 108-2611-M-002-005-, and 109-2636-B-002-006-.

Data Availability Statement: The data presented in this study are openly available at "140.109.172.56" of Environ. Ecol. Lab. of RCEC.

Acknowledgments: We thank the Taipei Fei-Tsui Reservoir Administration Bureau for assisting with fieldwork.

Conflicts of Interest: The authors declare no conflict of interest. 


\section{References}

1. Liu, S.C.; Fu, C.; Shiu, C.-J.; Chen, J.-P.; Wu, F. Temperature dependence of global precipitation extremes. Geophys. Res. Lett. 2009, 36. [CrossRef]

2. Chou, C.; Chiang, J.C.H.; Lan, C.-W.; Chung, C.-H.; Liao, Y.-C.; Lee, C.-J. Increase in the range between wet and dry season precipitation. Nat. Geosci. 2013, 6, 263-267. [CrossRef]

3. Emanuel, K. Increasing destructiveness of tropical cyclones over the past 30 years. Nat. Cell Biol. 2005, 436, 686-688. [CrossRef] [PubMed]

4. Webster, P.J.; Holland, G.J.; Curry, J.A.; Chang, H.-R. Changes in Tropical Cyclone Number, Duration, and Intensity in a Warming Environment. Science 2005, 309, 1844-1846. [CrossRef]

5. Knutson, T.R.; Mcbride, J.1.; Chan, J.; Emanuel, K.; Holland, G.; Landsea, C.; Held, I.; Kossin, J.P.; Srivastava, A.K.; Sugi, M. Tropical cyclones and climate change. Nat. Geosci. 2010, 3, 157-163. [CrossRef]

6. Toming, K.; Kotta, J.; Uuemaa, E.; Sobek, S.; Kutser, T.; Tranvik, L.J. Predicting lake dissolved organic carbon at a global scale. Sci. Rep. 2020, 10, 8471. [CrossRef]

7. Fan, C.-W. Particles dynamics in a deep reservoir triggered by typhoons. J. Hydrol. 2011, 406, 82-87. [CrossRef]

8. Lee, L.-C.; Hsu, T.-C.; Lee, T.-Y.; Shih, Y.-T.; Lin, C.Y.; Jien, S.-H.; Hein, T.; Zehetner, F.; Shiah, F.-K.; Huang, J.-C. Unusual Roles of Discharge, Slope and SOC in DOC Transport in Small Mountainous Rivers, Taiwan. Sci. Rep. 2019, 9, 1-9. [CrossRef] [PubMed]

9. Tseng, Y.-F.; Hsu, T.-C.; Chen, Y.-L.; Kao, S.-J.; Wu, J.-T.; Lu, J.-C.; Lai, C.-C.; Kuo, H.-Y.; Lin, C.-H.; Yamamoto, Y.; et al. Typhoon effects on DOC dynamics in a phosphate-limited reservoir. Aquat. Microb. Ecol. 2010, 60, 247-260. [CrossRef]

10. Jennings, E.; Jones, S.; Arvola, L.; Staehr, P.A.; Gaiser, E.; Jones, I.D.; Weathers, K.C.; Weyhenmeyer, G.A.; Chiu, C.-Y.; De Eyto, E. Effects of weather-related episodic events in lakes: An analysis based on high-frequency data. Freshw. Biol. 2012, 57, 589-601. [CrossRef]

11. Sparber, K.; Dalton, C.; De Eyto, E.; Jennings, E.; Lenihan, D.; Cassina, F. Contrasting pelagic plankton in temperate Irish lakes: The relative contribution of heterotrophic, mixotrophic, and autotrophic components, and the effects of extreme rainfall events. Inland Waters 2015, 5, 295-310. [CrossRef]

12. Chow, M.F.; Lai, C.-C.; Kuo, H.-Y.; Lin, C.-H.; Chen, T.-Y.; Shiah, F.-K. Long Term Trends and Dynamics of Dissolved Organic Carbon (DOC) in a Subtropical Reservoir Basin. Water 2017, 9, 545. [CrossRef]

13. Yeh, T.-C.; Liao, C.-S.; Chen, T.-C.; Shih, Y.-T.; Huang, J.-C.; Zehetner, F.; Hein, T. Differences in N loading affect DOM dynamics during typhoon events in a forested mountainous catchment. Sci. Total Environ. 2018, 633, 81-92. [CrossRef]

14. Cox, P.M.; Betts, R.A.; Jones, C.D.; Spal, S.A.; Totterdell, J.J. Acceleration of global warming due to carbon-cycle feedbacks in a coupled climate model. Nature 2000, 408, 184-187. [CrossRef] [PubMed]

15. Heimann, M.; Reichstein, M. Terrestrial ecosystem carbon dynamics and climate feedbacks. Nat. Cell Biol. 2008, 451, 289-292. [CrossRef] [PubMed]

16. Sabine, C.L.; Feely, R.A.; Gruber, N.; Key, R.M.; Lee, K.; Bullister, J.L.; Wanninkhof, R.; Wong, C.S.; Wallace, D.W.R.; Tilbrook, B.; et al. The Oceanic Sink for Anthropogenic $\mathrm{CO}_{2}$. Science 2004, 305, 367-371. [CrossRef]

17. Cole, J.J.; Prairie, Y.T.; Caraco, N.F.; McDowell, W.H.; Tranvik, L.J.; Striegl, R.G.; Duarte, C.M.; Kortelainen, P.; Downing, J.A.; Middelburg, J.J.; et al. Plumbing the global carbon cycle: Integrating inland waters into the terrestrial carbon budget. Ecosystems 2007, 10, 171-184. [CrossRef]

18. Hedges, J.I. Global biogeochemical cycles: Progress and problems. Mar. Chem. 1992, 39, 67-93. [CrossRef]

19. Hansell, D.A.; Carlson, C.A.; Repeta, D.J.; Schlitzer, R. Dissolved Organic Matter in the Ocean: A Controversy Stimulates New Insights. Oceanography 2009, 22, 202-211. [CrossRef]

20. Häder, D.-P.; Kumar, H.; Smith, R.; Worrest, R. Effects on aquatic ecosystems. J. Photochem. Photobiol. B Biol. 1998, 46, 53-68. [CrossRef]

21. Tranvik, L.J.; Downing, J.A.; Cotner, J.B.; Loiselle, S.A.; Striegl, R.G.; Ballatore, T.J.; Dillon, P.; Finlay, K.; Fortino, K.; Knoll, L.B.; et al. Lakes and reservoirs as regulators of carbon cycling and climate. Limnol. Oceanogr. 2009, 54, $2298-2314$. [CrossRef]

22. Pomeroy, L.R. The ocean's foodweb, a changing paradigm. BioScience 1974, 24, 499-504. [CrossRef]

23. Azam, F.; Fenchel, T.; Field, J.G.; Gray, J.; Meyer-Reil, L.; Thingstad, F. The Ecological Role of Water-Column Microbes in the Sea. Mar. Ecol. Prog. Ser. 1983, 10, 257-263. [CrossRef]

24. Duarte, C.M.; Agustí, S.; Vaqué, D.; Agawin, N.S.; Felipe, J.; Casamayor, E.O.; Gasol, J.M. Experimental test of bacteriaphytoplankton coupling in the Southern Ocean. Limnol. Oceanogr. 2005, 50, 1844-1854. [CrossRef]

25. Pomeroy, L.R.; Wiebe, W.J. Temperature and substrates as interactive limiting factors for marine heterotrophic bacteria. Aquat. Microb. Ecol. 2001, 23, 187-204. [CrossRef]

26. Tsai, J.-W.; Kratz, T.K.; Hanson, P.C.; Kimura, N.; Liu, W.-C.; Lin, F.-P.; Chou, H.-M.; Wu, J.-T.; Chiu, C.-Y. Metabolic changes and the resistance and resilience of a subtropical heterotrophic lake to typhoon disturbance. Can. J. Fish. Aquat. Sci. 2011, 68, 768-780. [CrossRef]

27. Tsuchiya, K.; Kuwahara, V.S.; Hamasaki, K.; Tada, Y.; Ichikawa, T.; Yoshiki, T.; Nakajima, R.; Imai, A.; Shimode, S.; Toda, T. Typhoon-induced response of phytoplankton and bacteria in temperate coastal waters. Estuar. Coast. Shelf Sci. 2015, 167, 458-465. [CrossRef] 
28. Felip, M.; Pace, M.; Cole, J. Regulation of planktonic bacterial growth rates: The effects of temperature and resources. Microb. Ecol. 1996, 31, 15-28. [CrossRef] [PubMed]

29. Novak, J.M.; Stone, K.C.; Watts, D.W.; Johnson, M.H. Dissolved Phosphorus Transport during Storm and Base Flow Conditions from An Agriculturally Intensive Southeastern Coastal Plain Watershed. Trans. ASAE 2003, 46, 1355. [CrossRef]

30. Zhanga, Q.; Blomquist, J.D. Watershed export of fine sediment, organic carbon, and chlorophyll-a to Chesapeake Bay: Spatial and temporal patterns in 1984-2016. Sci. Total Environ. 2018, 619, 1066-1078. [CrossRef]

31. Chen, S.; Lu, Y.; Dash, P.; Das, P.; Li, J.; Capps, K.; Majidzadeh, H.; Elliott, M. Hurricane pulses: Small watershed exports of dissolved nutrients and organic matter during large storms in the Southeastern USA. Sci. Total Environ. 2019, 689, 232-244. [CrossRef]

32. Fakour, H.; Lo, S.-L.; Lin, T.-F. Impacts of Typhoon Soudelor (2015) on the water quality of Taipei, Taiwan. Sci. Rep. 2016, 6, 25228. [CrossRef]

33. Warner, K.A.; Fowler, R.A.; Saros, J.E. Differences in the Effects of Storms on Dissolved Organic Carbon (DOC) in Boreal Lakes during an Early Summer Storm and an Autumn Storm. Water 2020, 12, 1452. [CrossRef]

34. Humbert, G.; Parr, T.B.; Jeanneau, L.; Dupas, R.; Petitjean, P.; Akkal-Corfini, N.; Viaud, V.; Pierson-Wickmann, A.-C.; Denis, M.; Inamdar, S.; et al. Agricultural Practices and Hydrologic Conditions Shape the Temporal Pattern of Soil and Stream Water Dissolved Organic Matter. Ecosystems 2020, 23, 1325-1343. [CrossRef]

35. Ogawa, H.; Tanoue, E. Dissolved Organic Matter in Oceanic Waters. J. Oceanogr. 2003, 59, 129-147. [CrossRef]

36. Pagano, T.; Bida, M.; Kenny, J.E. Trends in Levels of Allochthonous Dissolved Organic Carbon in Natural Water: A Review of Potential Mechanisms under a Changing Climate. Water 2014, 6, 2862-2897. [CrossRef]

37. Kalev, S.; Toor, G.S. Concentrations and Loads of Dissolved and Particulate Organic Carbon in Urban Stormwater Runoff. Water 2020, 12, 1031. [CrossRef]

38. Puczko, K.; Jekatierynczuk-Rudczyk, E. Extreme Hydro-Meteorological Events Influence to Water Quality of Small Rivers in Urban Area: A Case Study in Northeast Poland. Sci. Rep. 2020, 10, 1-14. [CrossRef]

39. Gasol, J.M.; Del Giorgio, P.A. Using flow cytometry for counting natural planktonic bacteria and understanding the structure of planktonic bacterial communities. Sci. Mar. 2000, 64, 197-224. [CrossRef]

40. Brussaard, C.P.D. Optimization of Procedures for Counting Viruses by Flow Cytometry. Appl. Environ. Microbiol. 2004, 70, 1506-1513. [CrossRef]

41. Fuhrman, J.A.; Azam, F. Thymidine incorporation as a measure of heterotrophic bacterioplankton production in marine surface waters: Evaluation and field results. Mar. Biol. 1982, 66, 109-120. [CrossRef]

42. Ducklow, H.W.; Carlson, C.A. Oceanic Bacterial Production. In Advances in Microbial Ecology; Springer: Berlin/Heidelberg, Germany, 1992; Volume 12, pp. 113-181.

43. Strock, K.E.; Saros, J.E.; Nelson, S.J.; Birkel, S.D.; Kahl, J.S.; McDowell, W. Extreme weather years drive episodic changes in lake chemistry: Implications for recovery from sulfate deposition and long-term trends in dissolved organic carbon. Biogeochemistry 2016, 127, 353-365. [CrossRef]

44. Fillela, M.; Rodriquez-Murillo, J. Long-term trends of organic carbon concentrations in freshwaters: Strength and weaknesses of existing evidence. Water 2014, 6, 1360-1418. [CrossRef]

45. Sucker, C.; Krause, K. Increasing dissolved organic carbon concentrations in freshwaters: What is the actual driver? iForest Biogeosciences For. 2010, 3, 106-108. [CrossRef]

46. Wheeler, P.; Watkins, J.; Hansing, R. Nutrients, organic carbon and organic nitrogen in the upper water column of the Arctic Ocean: Implications for the sources of dissolved organic carbon. Deep Sea Res. Part II Top. Stud. Oceanogr. 1997, 44, 1571-1592. [CrossRef]

47. Waterloo, M.J.; Oliveira, S.M.; Drucker, D.P.; Nobre, A.D.; Cuartas, L.A.; Hodnett, M.G.; Langedijk, I.; Jans, W.W.P.; Tomasella, J.; De Araújo, A.C.; et al. Export of organic carbon in run-off from an Amazonian rainforest blackwater catchment. Hydrol. Process. 2006, 20, 2581-2597. [CrossRef]

48. Chen, Y.-J.C.; Wu, S.-C.; Lee, B.-S.; Hung, C.-C. Behavior of storm-induced suspension interflow in subtropical Feitsui Reservoir, Taiwan. Limnol. Oceanogr. 2006, 51, 1125-1133. [CrossRef]

49. Dhillon, G.S.; Inamdar, S. Extreme storms and changes in particulate and dissolved organic carbon in runoff: Entering un-charted waters? Geophys. Res. Lett. 2013, 40, 1322-1327. [CrossRef]

50. Forel, F.A. Les ravins sous-lacustres des fleuves glaciaires. Comptes Rendus Académie Sci. 1885, 101, 725-728.

51. Mulder, T.; Syvitski, J.P.; Migeon, S.; Faugères, J.-C.; Savoye, B. Marine hyperpycnal flows: Initiation, behavior and related deposits. A review. Mar. Pet. Geol. 2003, 20, 861-882. [CrossRef]

52. Sterner, R. On the Phosphorus Limitation Paradigm for Lakes. Int. Rev. Hydrobiol. 2008, 93, 433-445. [CrossRef]

53. Milliman, J.D.; Kao, S. Hyperpycnal Discharge of Fluvial Sediment to the Ocean: Impact of Super-Typhoon Herb (1996) on Taiwanese Rivers. J. Geol. 2005, 113, 503-516. [CrossRef]

54. Holtan, H.; Kamp-Nielsen, L.; Stuanes, A.O. Phosphorus in soil, water and sediment: An overview. Hydrobiologia 1988, 170, 19-34. [CrossRef]

55. Reddy, K.; Kadlec, R.H.; Flaig, E.; Gale, P.M. Phosphorus Retention in Streams and Wetlands: A Review. Crit. Rev. Environ. Sci. Technol. 1999, 29, 83-146. [CrossRef] 
56. Cole, J.J.; Carpenter, S.R.; Kitchell, J.F.; Pace, M.L. Pathways of organic carbon utilization in small lakes: Results from a whole-lake $13 \mathrm{C}$ addition and coupled model. Limnol. Oceanogr. 2002, 47, 1664-1675. [CrossRef]

57. Jonsson, A.; Karlsson, J.; Jansson, M. Sources of carbon dioxide super saturation in clear water and humic lakes in northern Sweden. Ecosystems 2003, 6, 224-235. [CrossRef]

58. Raymond, P.A.; Hartmann, J.; Lauerwald, R.; Sobek, S.; McDonald, C.; Hoover, M.; Butman, D.; Striegl, R.; Mayorga, E.; Humborg, C.; et al. Global carbon dioxide emissions from inland waters. Nature 2013, 503, 355-359. [CrossRef] [PubMed] 